\title{
Corrosion of Orthodontic Pliers Using Different Sterilization Procedures
}

\section{Korrosionsverhalten kieferorthopädischer Zangen bei Anwendung verschiedener Sterilisationsverfahren}

\author{
Andrea Wichelhaus', Gert Brauchle², Matthias Mertmann³ ${ }^{3}$ Franz Günter Sander²
}

\begin{abstract}
Aim: The aim of this study was to investigate the corrosion resistance of orthodontic pliers from several manufacturers following different sterilization procedures, namely heat sterilization and the use of a disinfectant agent (Sekusept Extra $\mathrm{N}^{\circledR}$ ) in an ultrasonic bath.

Material and Methods: Employed in this study were ten distal-end cutters and ten Weingart pliers manufactured by Aesculap ${ }^{\circledR}$, ETM and Hu-Friedy ${ }^{\circledR}$, examined under electron microscopy for evidence of corrosion following 500 sterilization cycles. The corrosion data were recorded photographically and graphically. Metallographic microsections were prepared from each pair of pliers and were then analyzed by means of EDX measurements to assess the chemical alloy composition.

Results: The light and electron microscopic evaluation showed that both heat sterilization and high level disinfection caused corrosive changes on the pliers. However, the type of corrosion differed between the two sterilization methods. The main type of corrosion with Sekusept Extra ${ }^{\circledR}{ }^{\circledR}$ was pitting, while with heat sterilization it was surface corrosion. Heat sterilization was the type of corrosion that caused the most corrosive changes, regardless of which type of corrosion was considered. However, these results must be viewed critically, because pitting corrosion is obviously a more severe problem than surface corrosion.

In comparing the pliers of various manufacturers, differences were noted. However, it was difficult to rank them when the correct maintenance regime was adhered to.

The soldered joint gap was revealed to be a specific weak point, and that area proved to be inadequate due to qualities related to their production, particularly in the Hu-Friedy ${ }^{\circledR}$ pliers.
\end{abstract}

\section{Zusammenfassung}

Ziel: Das Ziel dieser Studie war es, kieferorthopädische Zangen verschiedener Hersteller auf ihre Korrosionsbeständigkeit nach mehreren Sterilisationsdurchgängen mit Hitzesterilisation und einem Desinfektionsmittel (Sekusept Extra ${ }^{\circledR}{ }^{\circledR}$ ) im Ultraschallbad zu vergleichen.

Material und Methoden: Bei der Studie wurden zehn Distalendcutter und zehn Weingartzangen der Firmen Aesculap ${ }^{\circledR}$, ETM und Hu-Friedy ${ }^{\circledR}$ nach 500 Sterilisationsdurchgängen sowohl lichtmikroskopisch als auch rasterelektronenmikroskopisch auf Korrosionserscheinungen untersucht. Die Korrosionserscheinungen wurden dabei sowohl fotografisch als auch statistisch in einem dafür angefertigten Auswertungsbogen festgehalten. Zudem wurden Schliffe der Zangen hergestellt, über die mit der EDX-Analyse die Legierung der jeweiligen Zangen ermittelt werden konnte.

Ergebnisse: Bei den licht- und rasterelektronischen Untersuchungen ergaben sich sowohl nach der Behandlung mit Hitzesterilisation als auch mit der High-level-Desinfektion korrosive Veränderungen an den Zangen. Es stellte sich heraus, dass Lochfraß die Hauptkorrosionsart bei der Behandlung der Zangen mit dem chemischen Desinfektionsmittel Sekusept Extra $N^{\circledR}$ war, während durch Hitzesterilisation hauptsächlich Flächenkorrosion verursacht wurde. Die Hitzesterilisation war das Sterilisationsverfahren, bei welchem unabhängig von der Korrosionsart mehr Korrosionsveränderungen auftraten. Dies muss jedoch kritisch betrachtet werden, da es sich bei Lochfraß um die eindeutig schwerwiegendere Korrosionsform handelt.

Wenn man die Hersteller miteinander vergleicht, so schnitten die Zangen unterschiedlich ab. Eine Rangfolge war schwierig aufzustellen, wenn der Anwender sich korrekt an die Pflegehinweise hielt.

\footnotetext{
'Department of Orthodontics and Paediatric Dentistry, University of Basle, Switzerland,

${ }^{2}$ Department of Orthodontics, University of Ulm, Germany,

${ }^{3}$ Institute of Materials, University of Bochum, Germany.

English version revised by Carol Cürten, Freiburg/Br.

Received: June 18, 2004; accepted: September 7, 2004
}

J Orofac Orthop 2004;65:501-11

DOI 10.1007/s00056-004-0417-9 
Conclusions: This study showed that heat sterilization leads to less corrosion than cold disinfection. Corroded pliers can be restored to a useable condition by re-polishing, though it is important that the instructions for their care be strictly adhered to.

Key Words: Corrosion - Orthodontic pliers - Disinfection · Sterilization
Der Lötspalt kristallisierte sich als besonderer Schwachpunkt heraus. Herstellungsbedingt waren dort, vor allem bei den Zangen von Hu-Friedy ${ }^{\circledR}$, insuffiziente Bereiche auszumachen.

Schlussfolgerungen: Die Studie zeigt, dass die Hitzesterilisation weniger Korrosionsschäden verursacht als die Kaltdesinfektion. Korrodierte Zangen können durch Politur wieder nutzbar gemacht werden. Es empfiehlt sich jedoch, die Pflegehinweise genau zu beachten.

Schlüsselwörter: Korrosion - Kieferorthopädische Zangen · Desinfektion - Sterilisation

\section{Einleitung}

Sowohl die Korrosion als auch das Stumpfwerden kieferorthopädischer Zangen sind Probleme, die häufig in der Kieferorthopädie auftreten, wie Untersuchungen von Borchmann [4, 5] zeigen. Die Korrosion kieferorthopädischer Zangen ist zum einen wegen denkbarer biologischer Reaktionen als auch aufgrund möglicher Qualitätsminderung des Werkstoffes von Wichtigkeit [15]. In diesem Zusammenhang ist der Begriff „rostfreier Stahl“, welcher als häufige Bezeichnung für Werkstoffe dient, irreführend, da es keinen Stahl auf dem Markt gibt, der keine Korrosion im Sinne von Rost zulässt. Die Korrosionsbeständigkeit kann der rostfreie Stahl nur dadurch erhöhen, dass er eine dichte Chromoxidschicht bildet. Das Problem, welches sich also bei der $\mathrm{Zu}-$ sammensetzung des Stahls stellt, ist die Suche nach einem idealen Verhältnis von Kohlenstoff und Chrom bzw. Nickel, da der Kohlenstoffgehalt zum Härten des Stahls notwendig ist. Andererseits erreicht man durch höhere Chrom- und Nickelanteile Rost- und Säurebeständigkeit. Um eine gute Schneidefähigkeit des Stahls zu erreichen, ist eine ausreichende Härte unumgänglich, was jedoch eine verminderte Rostbeständigkeit zur Folge hat.

Ein weiteres Problem stellen die Hartmetalleinsätze und die Gelenke der kieferorthopädischen Zangen dar. Durch die Passgenauigkeit im Gelenkbereich kann keine Luftzirkulation stattfinden. Dies hat zur Folge, dass dort kein rasches Trocknen möglich ist, was wiederum bedeutet, dass Reste von Leitungswasser oder von Desinfektionsmittellösungen wie z.B. Glutaraldehyd im Zusammenhang mit Thermosterilisation zu erheblichen Schäden führen können. Deshalb ist es von großer Bedeutung, besonders diese Stellen vor der Thermosterilisation oder nach der Sterilisation mit chemischen Lösungsmitteln, etwa durch Druckluft, zu trocknen. Die Verwendung von Hartmetalleinsätzen in kieferorthopädischen Zangen hat den Nachteil, dass in einem Instrument unterschiedliche Metalle entweder durch Lot oder durch mechanischen Halt miteinander verbunden sind. In wässrigem Milieu führt dies zu einer elektro-chemischen Potentialdifferenz und kann einen elektrolytischen Korrosionsprozess in Gang setzen. 


\section{Material and Methods}

Hot-air sterilization, as one of the methods of thermosterilization, was carried out at $200{ }^{\circ} \mathrm{C}$ for $10 \mathrm{~min}$, the shortest sterilization time allowed according to DAB 9/1986 [6, 7] (DAB $=$ German pharmacopeia). As time is of the essence in dental practice, the shortest possible sterilization time was chosen. The running of a dental practice demands that there be no unnecessary delays, and in this respect there is hardly any difference in the timing between hot-air sterilization and chemical sterilization with Sekusept Extra $\mathrm{N}^{\circledR}$. The pliers were rinsed with distilled water prior to sterilization to remove the alkaline and metallic ions found in tap water that can damage the metal surfaces [16]. Finally the pliers were thoroughly dried in order to reproduce normal working practices (soaking - drying - sterilizing). The drying is particularly relevant because iron reacts with moisture to create a layer of loosely-adhering surface rust (surface corrosion). In clinical practice it is important to ensure that the pliers be completely dry before inserting them into the sterilization equipment, to avoid such corrosion damage. This was why we not only dried, but dry-blasted the pliers with pressurized air prior to sterilization. This process also dried areas that could not be adequately dried with a cloth, such as the hinge area. The sterilization apparatus used was an autoclave from the manufacturer Heraeus (Hanau, Germany), model number 5000 (T 5090 E/T 5110 E) according to DIN standard 12880 [8]. For a comparison with heat sterilization, the pliers were placed in an ultrasonic bath with Sekusept Extra $\mathrm{N}^{\circledR}$. Sekusept Extra $\mathrm{N}^{\circledR}$ can be used in varying concentrations from 1 to $5 \%$ [12]. The degree of concentration affects the effective sterilization times, e.g for Mycobacterium tuberculosis from 1 hour at $1.5 \%$ to $15 \mathrm{~min}$ at $5 \%$. Using the solution in an ultrasonic bath also improves efficacy. It has been found that all the commonly tested infective agents are destroyed following a 5 minute immersion in 3\% Sekusept Extra ${ }^{\circledR}$ (Henkel Hygiene, Düsseldorf, Germany) [12]. There is however no advice available on testing for viruses when using the ultrasonic bath. Other reports using 0.5\% Sekusept Extra New Solution without application of an ultrasonic bath stated for example that HIV was inactivated in 4.77 logarithmic steps [12].

Sekusept Extra $\mathrm{N}^{\circledR}$ is effective against bacteria such as Mycobacterium tuberculosis, fungi, viruses such as hepatitis $\mathrm{B}$, and the AIDS agent HIV [12].

The disinfectant agent is composed of non-ionic tensides, cleaning promoters, antimicrobial agents, corrosion inhibitors, and coloring and perfume additives. $100 \mathrm{~g} \mathrm{Seku-}$ sept Extra New contains 6 g glutaraldehyde and $5 \mathrm{~g}$ benzalkonium chloride. There is no information available concerning the corrosion inhibitors in any reviews.

For our investigation we used a 5\% solution of Sekusept Extra $\mathrm{N}^{\circledR}$, prepared by mixing 1 liter of distilled water with $200 \mathrm{ml}$ Sekusept Extra $\mathrm{N}^{\circledR}$. In order to ensure that the correct
Für Korrosionsschäden an kieferorthopädischen Zangen gibt es viele Faktoren. Als häufigster Faktor wird jedoch das Autoklavieren, d.h. die Einwirkung von Feuchtigkeit in Kombination mit Hitze, genannt. Diese Vermutung wird durch Untersuchungen von Thompson \& Bogues [18] und Draeger \& Prüter [10] bestätigt.

\section{Material und Methoden}

Aus dem Bereich der thermischen Sterilisationsmittel wurde die Heißluftsterilisation bei $200{ }^{\circ} \mathrm{C}$ und 10 min Sterilisationszeit ausgewählt, welche nach DAB 9/1986 die kürzeste Sterilisationszeit erlaubt $[6,7]$. Dieses Verfahren wurde deshalb ausgewählt, da es in der Praxis wichtig ist, möglichst wenig Zeit für die Sterilisation zu benötigen. Der Praxisbetrieb kann somit ohne zeitliche Verzögerung ablaufen, wobei sich sowohl die Hitzesterilisation als auch die Sterilisation mit Sekusept Extra $\mathrm{N}^{\circledR}$ zeitlich kaum unterscheiden. Die Zangen wurden vor jedem Sterilisationsvorgang mit destilliertem Wasser abgespült, um im Leitungswasser befindliche alkalische und metallische Ionen, welche die Metalloberfläche schädigen können, zu entfernen [16]. Anschließend wurden die Zangen gründlich abgetrocknet, um die in vitro üblichen Arbeitsschritte (Einweichen - Abtrocknen - Sterilisieren) nachzustellen. Dem Abtrocknen kommt eine entscheidende Bedeutung $\mathrm{zu}$, da bei der Reaktion zwischen Eisen und feuchter Luft eine lose haftende Rostschicht (Oberflächenkorrosion) gebildet wird. In der Praxis ist vor jedem Sterilisationsdurchgang besonders darauf zu achten, dass die Zangen trocken in das Sterilisationsgerät gelangen, um derartige Korrosionsschäden zu vermeiden. Aus diesem Grund wurden in dieser Untersuchung die Zangen nicht nur abgetrocknet, sondern zusätzlich vor jedem Sterilisationsvorgang mit Druckluft trocken geblasen. Dadurch sollten auch Stellen, welche mit einem Tuch nicht zu erreichen sind, wie zum Beispiel das Zangengelenk, trocken sein. Als Sterilisationsgerät wurde ein Trockenschrank der Baureihe 5000 (T 5090 E/T 5110 E) nach DIN 12880 [8] der Firma Heraeus (Hanau, Deutschland) benutzt. Als Vergleich zur Thermo-sterilisation diente das Einlegen der Zangen in Sekusept Extra $\mathrm{N}^{\circledR}$ im Ultraschallbad. Bei Sekusept Extra $\mathrm{N}^{\circledR}$ kann die Anwendungskonzentration nach Herstellerangabe im Bereich von $1-5 \%$ variiert werden [12]. Es ändert sich dementsprechend die Einwirkungszeit - z.B. bei Tuberkulose von 1 Stunde bei $1,5 \%$ auf 15 min bei 5\%. Die Anwendung der Desinfektionslösung im Ultraschallbad bringt eine zusätzliche Wirkungsverstärkung. Alle getesteten Keime im Gutachten über die Wirksamkeit von Sekusept Extra $\mathrm{N}^{\circledR}$ der Firma Henkel Hygiene (Düsseldorf, Deutschland) waren nach $5 \mathrm{~min}$ in $3 \%$ igem Ultraschallbad abgetötet [12]. Es liegen jedoch keine Gutachten über eine virologische Prüfung im Ultraschallbad vor, dafür aber andere Gutachten ohne Ultraschallbad, in denen z.B. die Inaktivierung von HIV durch eine 0,5\%ige Sekusept-Extra-Neu-Lösung mit 4,77 log-Stufen angegeben wird [12]. 
concentration had been achieved, it was left to stand for 1 hour. The solution was replaced daily to ensure the concentration did not change. After sterilization the pliers were rinsed for $5 \mathrm{~s}$ with distilled water to remove any corrosive agents from the exposed surfaces. Following heat sterilization, the pliers were dried with pressurized air. Each sterilization process with 5\% Sekusept Extra $\mathrm{N}^{\circledR}$ was carried out at room temperature for $5 \mathrm{~min}$. Each pair of pliers was sterilized 500 times.

For this investigation we used ten distal-end cutters and ten Weingart pliers from three different manufacturers (Figure 1). The distal-end cutters from Ormco had a soldered hard metal insert. Those from Hu-Friedy ${ }^{\circledR}$ had a soldered cutting edge that however was not made of hard metal, whereas those from Aesculap ${ }^{\circledR}$ had a special annealed blade to avoid the need for a soldered joint.

The following distal-end cutters were tested:

1. Universal distal-end cutter Nr. 678-101, Hu-Friedy ${ }^{\circledR}$ (Leimen, Germany)

2. Distal-end cutter Nr. DP542R, Aesculap ${ }^{\circledR}$ (Tuttlingen, Germany)

3. Small distal-end cutter Nr. 1016-S, ETM (Ormco, Glendora, CA, USA)

In addition the following Weingart pliers were tested:

1. Ortho Weingart pliers Nr. 678-201, Hu-Friedy ${ }^{\circledR}$ (Leimen, Germany)

2. Weingart pliers Nr. DP036R, Aesculap ${ }^{\circledR}$ (Tuttlingen, Germany)

3. Weingart pliers Nr. 158, ETM (Ormco, Glendora, CA, USA)

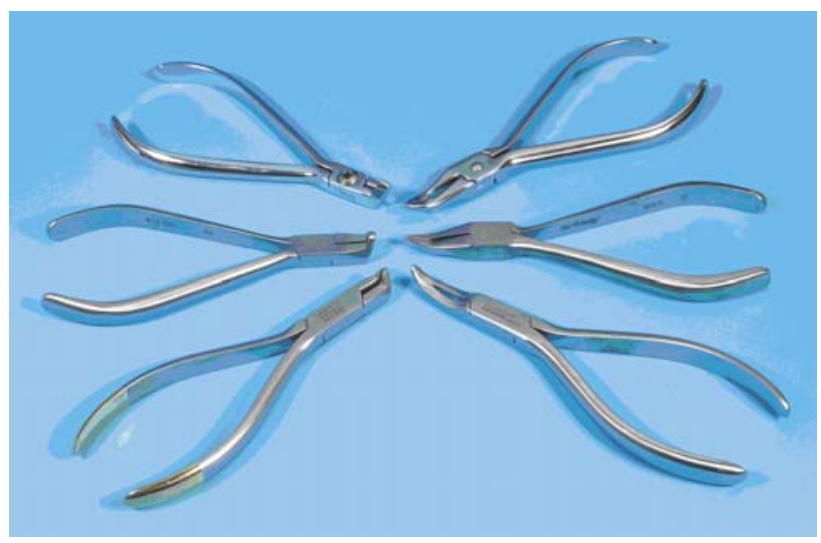

Figure 1. The distal-end cutters and Weingart pliers used in this study.

Abbildung 1. Die in der vorliegenden Studie untersuchten Distalendcutter und Weingartzangen im Überblick.
Sekusept Extra $\mathrm{N}^{\circledR}$ ist wirksam gegen Bakterien (auch Tbc), Pilze und Viren einschließlich Hepatitis-B-Viren und AIDS-Erreger (HIV) [12].

Das Desinfektionsmittel setzt sich aus nicht ionischen Tensiden, Reinigungsverstärkern, antimikrobiellen Wirkstoffen, Korrosionsinhibitoren sowie Farb- und Duftstoffen zusammen. In $100 \mathrm{~g}$ Sekusept Extra Neu sind $6 \mathrm{~g}$ Glutaral und 5 g Benzalkoniumchlorid enthalten. Auf die Korrosionsinhibitoren, welche in der Lösung enthalten sind, wird leider in keinem Gutachten eingegangen.

Bei der Untersuchung wurde eine 5\% ige Lösung von Sekusept Extra $\mathrm{N}^{\circledR}$ angesetzt; dazu wurde jeweils 11 destilliertes Wasser mit 200 ml Sekusept Extra $\mathrm{N}^{\circledR}$ gemischt. Danach wurde diese, um die richtige Konzentrationswirkung zu erreichen, 1 Stunde zum Einwirken stehen gelassen. Die Lösung wurde täglich neu angesetzt, um keine Konzentrationsunterschiede zu erhalten. Die Zangen wurden nach jedem Durchgang ca. 5 s mit destilliertem Wasser abgespült, um die Oberflächen der Zangen von den korrodierenden Wirkstoffen der Desinfektionslösung zu reinigen. Die Zangen wurden wie bei der Thermosterilisation anschließend trocken geblasen. Jeder Durchgang dauerte 5 min und fand in einer 5\% igen Desinfektionslösung mit Sekusept Extra $\mathrm{N}^{\circledR}$ bei Raumtemperatur statt. Jede Zange wurde 500-mal sterilisiert.

Für die Untersuchung wurden je zehn Distalendcutter und zehn Weingartzangen von drei verschiedenen Firmen ausgewählt (Abbildung 1). Die Distalendcutter von Ormco weisen Hartmetalleinsätze auf. Bei den Distalendcuttern von $\mathrm{Hu}-$ Friedy ${ }^{\circledR}$ ist eine Schneide eingelötet, welche jedoch nicht aus Hartmetall bestand, während bei Aesculap ${ }^{\circledR}$ die Schneide speziell vergütet war, sodass auf eine Lötung verzichtet werden konnte.

Es wurden folgende Distalendcutter untersucht:

1. Universal Distalendcutter Nr. 678-101, Hu-Friedy ${ }^{\circledR}$ (Leimen, Deutschland)

2. Distale Drahtschneidezange Nr. DP542R, Aesculap ${ }^{\circledR}$ (Tuttlingen, Deutschland)

3. Small Distalendcutter Nr. 1016-S, ETM (Ormco, Glendora, CA, USA)

Zudem wurden folgende Weingartzangen untersucht:

1. Ortho Zange Weingart Nr. 678-201, Hu-Friedy ${ }^{\circledR}$ (Leimen, Deutschland)

2. Drahtfasszange Weingart Nr. DP036R, Aesculap ${ }^{\circledR}$ (Tuttlingen, Deutschland)

3. Weingartzange Nr. 158, ETM (Ormco, Glendora, CA, USA)

Die rasterelektronenmikroskopische Untersuchung sowie die energiedispersive Röntgenanalyse wurden mit dem Rasterelektronenmikroskop Zeiss DSM926 ${ }^{\circledR}$ (Zeiss, Ober- 
The scanning electron microscope investigation was carried out using the electron microscope Zeiss DSM926 ${ }^{\circledR}$ (Zeiss, Oberkochen, Germany). The microscope produced a threedimensional picture from sequential scans of the tested surface that could be viewed on a monitor. An energy-dispersive X-ray EDX analysis was carried out. The sample was subjected to a stream of electrons that in this study had an acceleration force of $20 \mathrm{kV}$ [17]. This technique releases electrons from the sample and X-rays are discharged. The $\mathrm{X}$-ray beam was detected with a SiLi semiconductor in the associated EDX-device as manufactured by EDAX (EDAX Germany, Königstein im Taunus, Germany) Type 9800. This delivered an analysis of the surface in the $\mu$-region. Depending on the energy levels of the absorbed X-ray beam, it was possible to obtain a chemical breakdown of the tested sample [20]. From the recordings, similar quantums of x-rays were collected and added together to produce a visible peak shown on the monitor [11, 13]. The depth of penetration is dependent on the thickness of the material and the acceleration voltage. For the photographic documentation, we used a data recorder from the Nippon Kogaku K. K. (Tokyo, Japan) with a Rodagon objective from Rodenstock (Munich, Germany) and Ilford FP 4 plus film (Ilford Mobberley, Cheshire, England).

The pliers were also examined under a light microscope.

To facilitate this, grindings were taken from three distalend cutters and from three Weingart pliers that had been subjected to 500 sterilization cycles and were randomly chosen from the 60 pliers tested. In order to have a control with which to make a comparison, we examined pliers after each 100 sterilization cycles with a stereo microscope at $5 \mathrm{x}$ magnification. They were examined at specific sites, i.e., the cutting edge, the soldered area, the distal-end cutters' hinge joint, and the Weingart pliers' corrugated surface. The analysis was performed using a specifically-designed evaluation form (Figure 2). We used an incident light microscope of type SZ$\mathrm{PT}^{\circledR}$ from Olympus (Olympus Deutschland GmbH, Hamburg, Germany). Optical documentation was recorded using an OM $10^{\circledR}$ camera from Olympus loaded with an Ilford FP 4 plus film (Ilford Mobberley, Cheshire, England).

The statistical analysis was carried out using the Median test, also called Fisher's exact test. Fisher's test determines the probability for two independent random samples with two dichotomous entireties. The Fisher's test is a speciality of the $\chi^{2}$ test and can be applied even if the statistic sample and the expected frequencies are small. Fisher's test was performed to evaluate the differences between the proportions using a $2 \times 2$ contingency table.

\section{Results}

The light and electron microscopic evaluation showed that both heat sterilization and high level disinfection caused corrosive changes on the pliers (Figures 8-11). Changes in

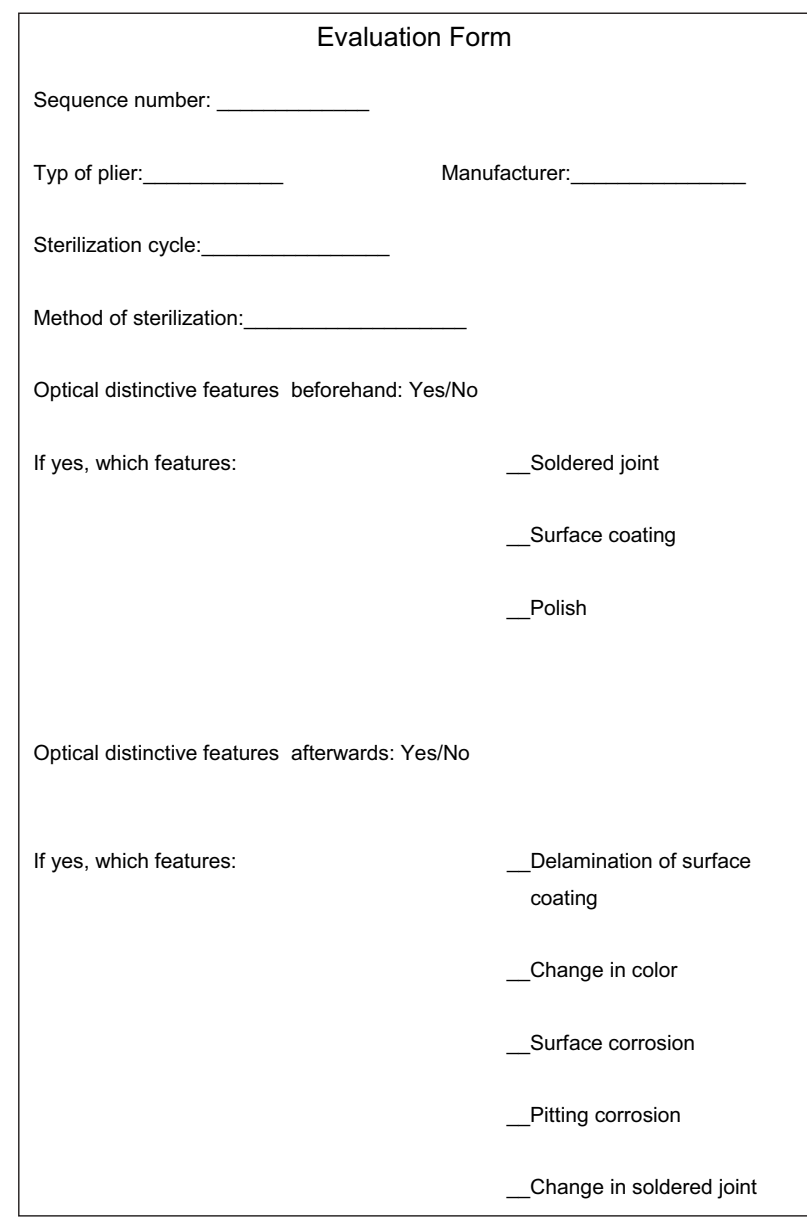

Figure 2. Evaluation form of the light microscopic analysis.

Abbildung 2. Auswertungsbogen der lichtmikroskopischen Untersuchung.

kochen, Deutschland) durchgeführt. Das Mikroskop ermöglichte eine dreidimensionale Ansicht der Probenoberflächen als zeitsequenzielles Bild an einem Monitor. Die EDX-Analyse erfolgte mit energiedispersiver Röntgenstrahlung, wobei die Probe mit einem Elektronenstrahl, in dieser Studie mit einer Beschleunigungsspannung von 20 $\mathrm{kV}$ erzeugt, beschossen wurde [17]. Bei diesem Vorgang werden Elektronen aus den Proben ausgelöst und Röntgenstrahlen freigesetzt. Die Röntgenstrahlung wurde mit einem SiLi-Halbleiter der angeschlossenen EDX-Einheit, Typ 9800, der Firma EDAX (EDAX Germany, Königstein im Taunus, Deutschland) detektiert. Diese lieferte eine Oberflächenanalyse im $\mu$-Bereich. Anhand des Energieniveaus der aufgenommenen Röntgenstrahlung erhält man eine chemische Aufschlüsselung der untersuchten Proben [20]. Dabei werden die Röntgenquanten gleicher Energie gesammelt, aufaddiert und auf dem Bildschirm als Peak sichtbar gemacht [11,13]. Die Eindringtiefe ist abhängig 


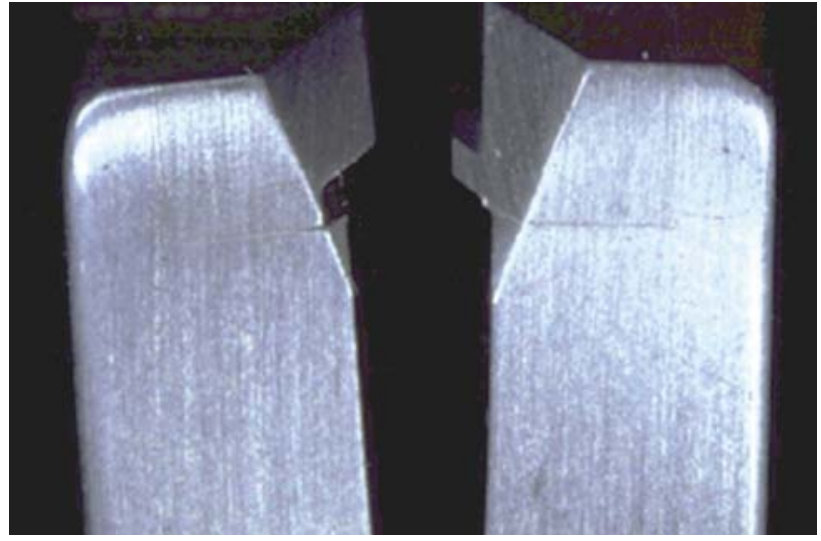

Figure 3. Changes in the soldered joint of a distal-end cutter from HuFriedy ${ }^{\circledR}$ after 500 cycles of cold disinfection.

Abbildung 3. Lötspaltveränderung bei einem Distalendcutter von HuFriedy ${ }^{\circledR}$ nach 500 Zyklen mit der Kaltdesinfektion.

the soldered area were especially evident in the Hu-Friedy ${ }^{\circledR}$ distal-end cutters (Figure 9). However, this was not surprising, as the soldered area of the ten Hu-Friedy ${ }^{\circledR}$ distal-end cutters was of poorer quality than that of the other manufacturers (Figure 3). The distal-end cutters from ETM showed less extensive damage in the soldered area. With a total of 500 sterilization cycles, such changes in the soldered areas were observed in the $\mathrm{Hu}$-Friedy ${ }^{\circledR}$ pliers after only 100 cycles, whereas the distal-end cutters from ETM did not reveal changes until after 400 cycles. Changes in the soldered area occurred in all samples with heat sterilization.

Pitting occurred only after the use of the disinfectant agent Sekusept Extra $N^{\circledR}$. This was due to corrosive elements such as glutaraldehyde and benzalkonium chloride.

Pitting was evident in both the distal-end cutters and the Weingart pliers, but the extent of damage was dependent on the manufacturer (Figure 10). The least-affected pliers were

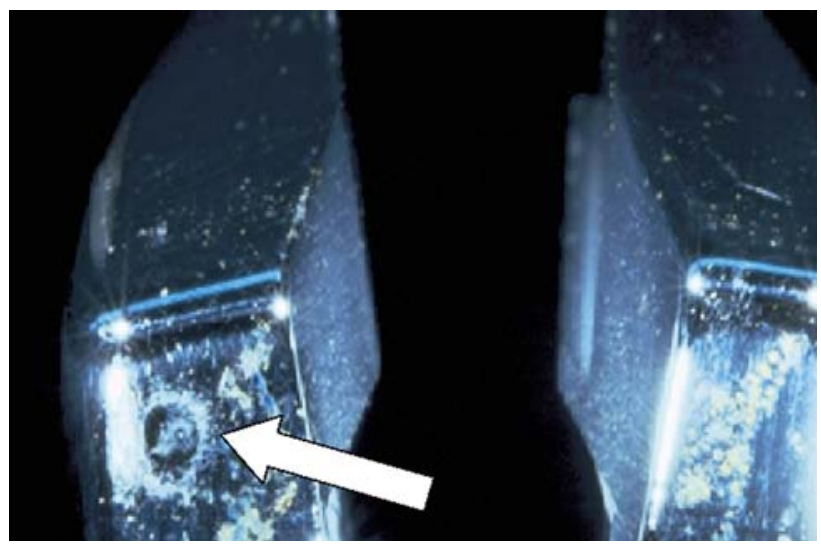

Figure 4. Pitting in a distal-end cutter from ETM (magnification $\times 13$ ).

Abbildung 4. Lochfraß bei einem Distalendcutter von ETM bei 13 facher Vergrößerung. von der Beschleunigungsspannung und der Dichte des Materials. Für die fotografische Dokumentation wurde das Registriergehäuse der Firma Nippon Kogaku K. K. (Tokio, Japan) mit einem Rodagon Objektiv (Rodenstock, München, Deutschland) und Ilford FP 4 plus Filmen der Firma Ilford (Mobberley, Cheshire, England) eingesetzt.

Zusätzlich wurden die Zangen lichtmikroskopisch untersucht.

Schliffe wurden von drei Distalendcuttern sowie von drei Weingartzangen angefertigt, welche nach 500 Sterilisationsdurchgängen aus den 60 getesteten Zangen frei gewählt wurden. Um sinnvolle Kontrollabstände zu haben, wurden die Zangen nach je 100 Sterilisationsdurchläufen mit einem Stereomikroskop bis zu einer fünffachen Vergrößerung auf mögliche Schäden an den Prädilektionsstellen wie Schneidekante, Lötstelle und Zangengelenk beim Distalendcutter und der geriffelten Oberfläche bei der Weingartzange untersucht. Dazu wurde ein eigener Auswertungsbogen angefertigt (Abbildung 2). Als Mikroskop benutzten wir dabei das Auflichtmikroskop SZ-PT ${ }^{\circledR}$ der Firma Olympus (Olympus Deutschland $\mathrm{GmbH}$, Hamburg, Deutschland). Zur optischen Dokumentation diente die Kamera OM10 ${ }^{\circledR}$ der Firma Olympus mit dem Film Ilford FP 4 plus (Ilford Mobberley, Cheshire, England).

Die statistische Auswertung wurde mit dem MedianTest, der auch als Fisher's exact-test bezeichnet wird, durchgeführt. Der Fisher-Test als eine Sonderform des $\chi^{2}$-Tests bestimmt den Wahrscheinlichkeitswert für zwei unabhängige Stichproben mit zwei dichotomen Gesamtheiten. Mit dem Fisher-Test lässt sich eine Vierfelderverteilung prüfen, auch wenn die Stichprobe und damit die erwarteten und beobachteten Häufigkeiten klein sind.

\section{Ergebnisse}

Bei den licht- und rasterelektronischen Untersuchungen ergaben sich sowohl nach der Behandlung mit Hitzesterilisation als auch mit der High-level-Desinfektion korro-

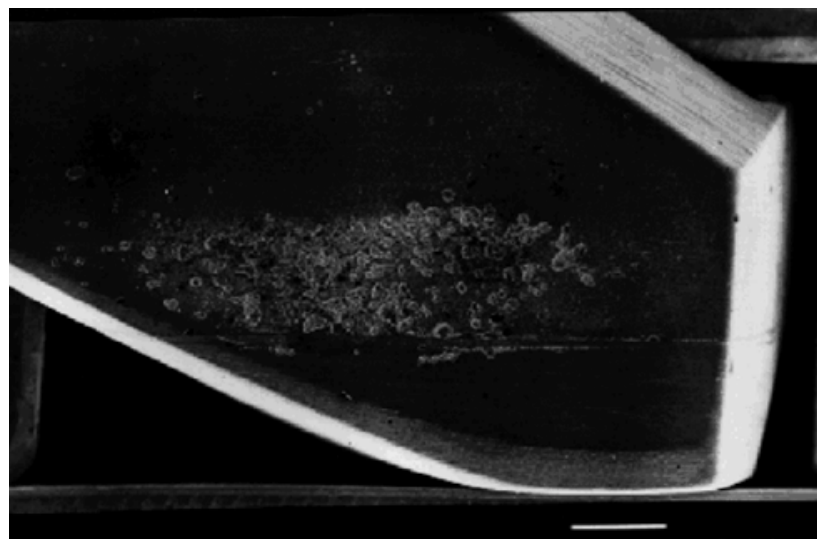

Figure 5. Pronounced pitting in a distal-end cutter from Hu-Friedy ${ }^{\circledR}$.

Abbildung 5. Ausgeprägter Lochfraß bei einem Distalendcutter von HuFriedy ${ }^{\circledR}$. 
those from Aesculap ${ }^{\circledR}$, as only two pairs of their pliers showed pitting, and then only after 300 cycles. The ETM pliers also showed pitting after 300 cycles, but in six pairs of pliers. The $\mathrm{Hu}$-Friedy ${ }^{\circledR}$ pliers showed pitting after only 200 cycles, but only in four pairs of pliers. Following 500 cycles, all the pliers from ETM and Hu-Friedy ${ }^{\circledR}$ treated with chemical disinfection demonstrated pitting. Only two pairs of Aesculap ${ }^{\circledR}$ pliers were affected. Pitting was clearly visible under the light microscope (Figure 4) and the electron microscope (Figure 5). The appearance of pitting is a typical indication of chemical disinfection. The main culprits are chloride and bromide ions.

Delamination was only present in ETM pliers, as, among all instruments tested, only theirs had a chrome surface coating. Delamination occurred after 200 cycles and was evident in all distal-end cutters and Weingart pliers after 500 cycles. This could best be seen under electron microscopy (Figures 6 and 7). Delamination occurred to a similar degree, regardless of whether heat or chemical sterilization was used (Figure 11).

The statistical analysis with the median test revealed the following results:

In comparing heat sterilization with Sekusept Extra $\mathrm{N}^{\circledR}$ without taking into account the type of corrosion, cold sterilization caused significantly less corrosion than did heat sterilization ( $p=0.0046)$. One must consider these findings with caution, however, since the corrosion caused by heat sterilization was not so detrimental to the pliers' stability as was the pitting corrosion caused by Sekusept Extra $N^{\circledR}$. Cold disinfection proved superior statistically, yet when utensil stability is considered, heat sterilization is better, as no pitting occurred. Surface corrosion was only seen with heat steriliza-

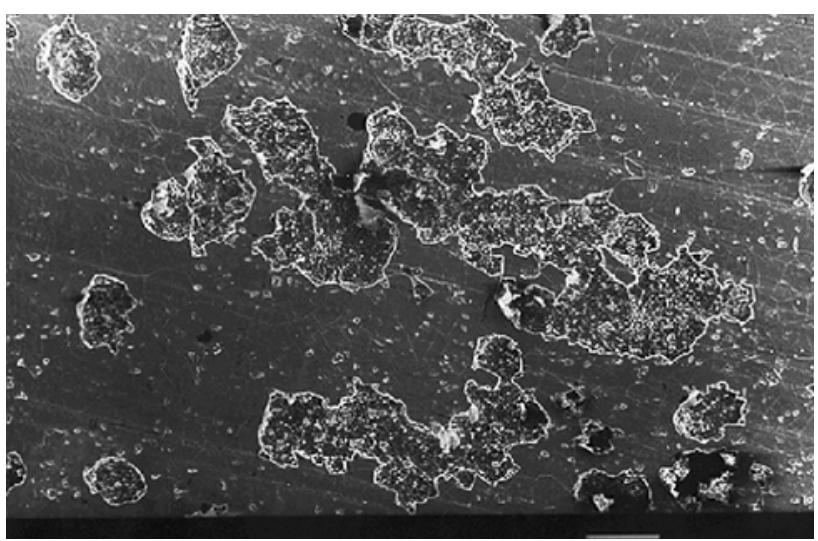

Figure 6. Delamination of the surface of a pair of ETM pliers (magnification $\times 100$ ). The delamination has been initially verified after 200 cycles and was visible on all pliers after 500 cycles.

Abbildung 6. Beschichtungsablösung an der Oberfläche einer ETM-Zange bei 100 facher Vergrößerung. Die Beschichtungsablösung konnte zum ersten Mal nach 200 Zyklen festgestellt werden und war nach 500 Durchgängen bei allen Zangen sichtbar. sive Veränderungen an den Zangen (Abbildungen 8-11). Veränderungen an der Lötstelle traten besonders bei den Distalendcuttern der Firma Hu-Friedy ${ }^{\circledR}$ auf (Abbildung 9). Dies war jedoch zu erwarten, da die Lötstelle der 10 untersuchten Distalendcuttern von Hu-Friedy ${ }^{\circledR}$ im Vergleich mit den Distalendcuttern der anderen Hersteller unzureichend verarbeitet war (Abbildung 3). Bei den Distalendcuttern von ETM konnten auch Veränderungen des Lötspaltes festgestellt werden, jedoch nicht in solchem Ausmaß. Bei insgesamt 500 Sterilisationsdurchgängen je Zange waren Lötstellenveränderungen bei den Zangen von Hu-Friedy ${ }^{\circledR}$ schon nach 100 Durchgängen zu erkennen, während sie bei den Distalendcutter von ETM erst nach 400 Durchgängen zu sehen waren. Die Lötstellenveränderungen traten vor allem bei der Thermosterilisation auf.

Lochfraß (Pitting) trat nur nach der Desinfektion mit Sekusept Extra $\mathrm{N}^{\circledR}$ auf. Dies lässt sich auf die korrosiven Stoffe wie Glutaral und Benzalkoniumchlorid zurückführen.

Der Lochfraß konnte sowohl bei den Weingartzangen als auch bei den Distalendcuttern ausgemacht werden, jedoch abhängig vom Hersteller in unterschiedlichem Ausmaß (Abbildung 10). Am besten schnitten die Zangen von Aesculap ${ }^{\circledR}$ $\mathrm{ab}$, bei denen nur an zwei Zangen Lochfraß auftrat. Zudem wurde Lochfraß erst nach 300 Durchgängen festgestellt. Bei den Zangen von ETM trat der Lochfraß zwar auch erst nach 300 Durchgängen auf, jedoch bei insgesamt sechs Zangen. Bei Hu-Friedy ${ }^{\circledR}$ trat Lochfraß schon nach 200 Durchgängen auf, jedoch nur bei vier Zangen. Nach 500 Durchgängen konnte bei allen Zangen von ETM und Hu-Friedy ${ }^{\circledR}$, die mit Sekusept Extra $\mathrm{N}^{\circledR}$ behandelt waren, Lochfraß nachgewiesen werden. Bei Aesculap ${ }^{\circledR}$ waren dies jedoch nur zwei Zangen. Lochfraß

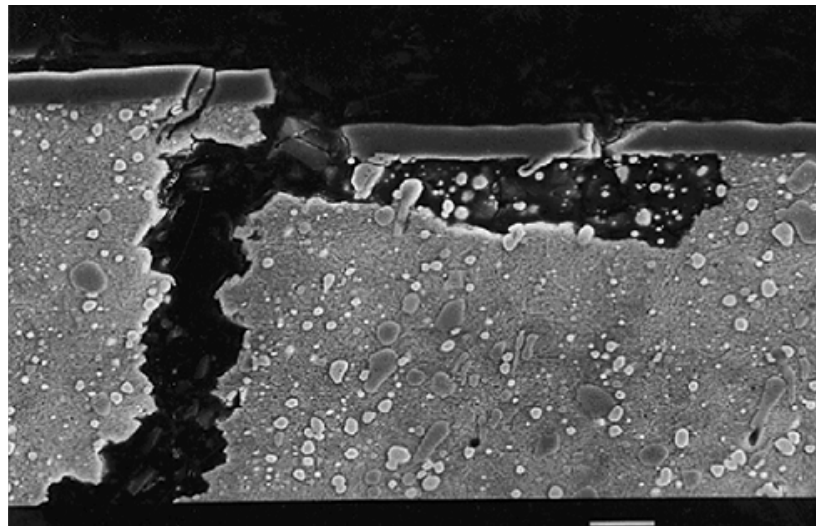

Figure 7. Clearly visible cracks in a pair of ETM pliers (magnification $\times$ 900)

Abbildung 7. Deutlich erkennbare Rissbildung an einer ETM-Zange bei 900facher Vergrößerung. 


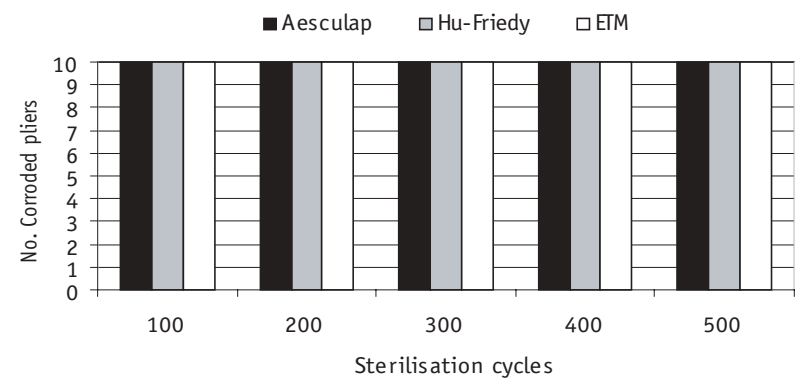

Figure 8. Surface corrosion of the pliers following sterilization at $200^{\circ} \mathrm{C}$. Corrosion marks were visible already after 100 sterilization cycles.

Abbildung 8. Oberflächenkorrosion der Weingartzangen bei Thermosterilisation mit $200^{\circ} \mathrm{C}$. Bereits nach 100 Sterilisationszyklen konnte Korrosion bei allen Zangen festgestellt werden.

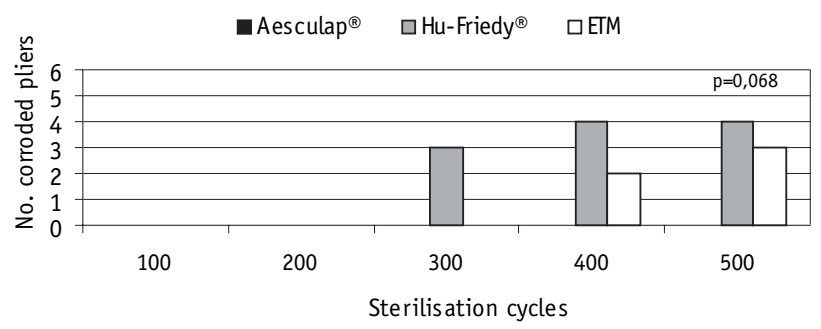

Figure 9. Changes in the soldered joint of distal-end cutters after thermosterilization. No significant difference was observed between quantitative corrosion of the pliers from Hu-Friedy ${ }^{\circledR}$ and ETM after 500 cycles ( $p$ $=0.068$ ). The Aesculap ${ }^{\circledR}$ distal-end cutter did not show any corrosion marks because the manufacturer used a hardening process rather than soldering techniques.

Abbildung 9. Lötstellenveränderung der Distalendcutter bei Anwendung der Thermosterilisation. Nach 500 Sterilisationszyklen konnte kein Unterschied zwischen dem quantitativen Korrosionsbefall der Zangen von HuFriedy ${ }^{\circledR}$ und ETM festgestellt werden $(p=0,068)$. Distalendcutter von Aesculap ${ }^{\circledR}$ zeigten keine Korrosion, da herstellerbedingt durch eine spezielle Vergütung der Schneide auf eine Lötung verzichtet wurde.

tion in pliers from each of the different manufacturers, and that was due to a combination of moisture and heat. This type of degradation was visible after 100 cycles in both the Weingart pliers and distal-end cutters (Figure 8). Surface corrosion producing visible rust affected hinge joints in particular, an area inherently more susceptible to residual moisture.

A comparison of the changes in the soldered joint could only be made between the pliers from ETM und Hu-Friedy ${ }^{\circledR}$ that had that type of joint. Three pliers from ETM showed changes in the soldered area (Figure 9). Four to five distalend cutters from Hu-Friedy ${ }^{\circledR}$ were similarly affected after 500 cycles. The $\mathrm{p}$ value was 0.068 , proving that there was no significant difference between the manufacturers.

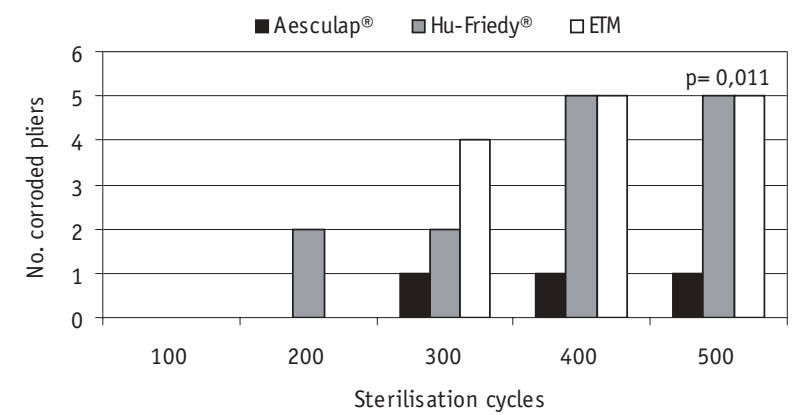

Figure 10. Pitting of pliers after 500 cycles of disinfection. The pliers from ETM and Hu-Friedy ${ }^{\circledR}$ are less resistant against pitting $(p=0.068)$.

Abbildung 10. Lochfraß der Weingartzangen nach 500 Zyklen der Kaltdesinfektion. Die Zangen von ETM und Hu-Friedy ${ }^{\circledR}$ sind deutlich anfälliger gegenüber Lochfraß $(p=0,068)$.

ließ sich optisch sowohl im Auflichtmikroskop (Abbildung 4) als auch im Rasterelektronenmikroskop (Abbildung 5) sehr gut erkennen. Das Erscheinen von Lochfraß war ein typisches Zeichen für den Einsatz chemischer Desinfektionsmittel. Die hauptsächlichen Verursacher sind Chlor- und Bromionen.

Beschichtungsablösungen kamen nur bei Zangen von ETM vor, da nur diese von allen untersuchten Zangen eine Oberflächenbeschichtung aus Chrom hatten. Die Beschichtungsablösung konnte zum ersten Mal nach 200 Durchgängen festgestellt werden und war nach 500 Durchgängen sowohl bei allen Weingartzangen als auch bei allen Distalendcuttern sichtbar. Am besten war diese im Rasterelektronenmikro-skop zu erkennen (Abbildungen 6 und 7). Die Beschichtungsablösung trat sowohl bei der Hitzesterilisation als auch bei der High-level-Desinfektion in gleichem Maße auf (Abbildung 11).

Bei der statistischen Auswertung ergaben sich folgende Ergebnisse:

Der Vergleich der Hitzesterilisation mit Sekusept Extra $\mathrm{N}^{\circledR}$, ohne Berücksichtigung der Korrosionsart, ergab, dass bei der Kaltsterilisation signifikant weniger Korrosionserscheinungen auftraten $(p=0,0046)$. Dieses Ergebnis ist jedoch differenziert zu betrachten, da die Korrosion durch Hitzesterilisation im Vergleich zum Lochfraß als Hauptkorrosionsart nach Anwendung mit Sekusept Extra $\mathrm{N}^{\circledR}$ weniger schwerwiegende Auswirkungen auf die Stabilität der Zangen hatte. Rein statistisch schnitt also die Kaltdesinfektion besser ab, unter Stabilitätsaspekten aber die Hitzesterilisation, da bei der Hitzesterilisation kein Lochfraß auftrat. Oberflächenkorrosion wurde nur bei der Hitzesterilisation beobachtet. Dies ist eine typische Korrosionsart, welche durch die Kombination von Wasser und Hitze verursacht wird. Sie trat signifikant bei den Weingartzangen und bei den Distalendcuttern nach 100 Sterilisationszyklen und, sichtbar als so genannter Rost, besonders an den Gelenken der Zangen auf (Abbildung 8). Dies lässt sich dadurch erklären, dass man diese Stellen beim Abtrocknen kaum erreicht. 


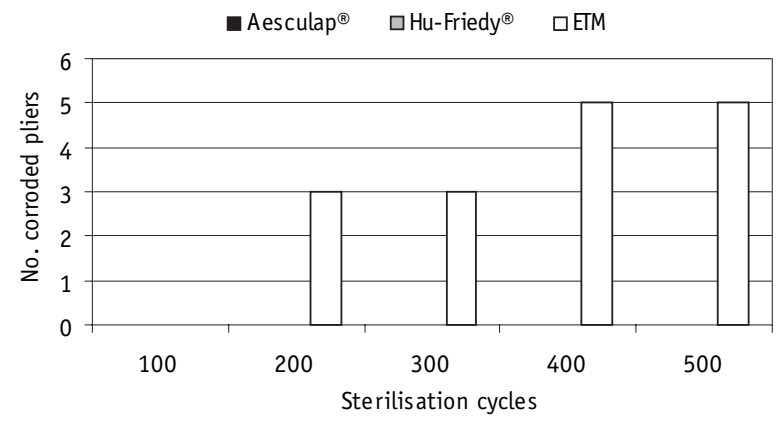

Figure 11. Delamination of ETM pliers.

Abbildung 11. Beschichtungslösung der ETM-Zangen.

Pitting occurred only with Sekusept Extra $\mathrm{N}^{\circledR}$ (Figure 10). The pliers from ETM und Hu-Friedy ${ }^{\circledR}$ had significantly more pitting than those from Aesculap ${ }^{\circledR}(p=0.011)$. Delamination was only present in the ETM pliers, as only they had a chromium surface layer (Figure 11). The loss was similar for both heat and high-concentration chemical disinfection.

\section{Discussion}

In this study a comparison was made of the sterilization of orthodontic pliers with heat sterilization and high-concentration disinfection with Sekusept Extra $\mathrm{N}^{\circledR}$. Heat sterilization was chosen because it is a method commonly used in practice and there are data published on the relationship between heat sterilization and corrosion [1, 3, 14]. Sekusept Extra $\mathrm{N}^{\circledR}$ was used in this study because, although it is not currently used in practice, it may be in the future, as it has already been proven to be a fast, effective and potent disinfectant agent [2].

The advantage of heat sterilization as opposed to cold sterilization with Sekusept Extra $\mathrm{N}^{\circledR}$ is its ease of use, meaning that trained staff (dental assistants) can carry out the procedure after appropriate instruction. A further advantage is the time benefit so important in practice. This fast method also has cost advantages, as less equipment is required. The expenses involved, however, of using the sterilization agent are not particularly high in comparison with other methods.

The pliers were examined for corrosion under light and electron microscopy. The characteristics of the corrosion damage observed were statistically analyzed so that the type of corrosion could be accurately assessed against DIN standards [9]. What is important is that surface corrosion could be distinguished from pitting erosion. These two types of corrosion can be qualitatively distinguished. Whereas surface corrosion does not affect the alloy to any depth, pitting erosion is associated with deeper penetration and can there-
Die Untersuchung im Bereich der Lötstelle war nur für die Zangen von ETM und Hu-Friedy ${ }^{\circledR}$ möglich, die solche Lötstellen haben. Sie ergab, dass sich bei drei Zangen von ETM eine Veränderung zeigte (Abbildung 9). Die Distalendcutter von $\mathrm{Hu}$-Friedy ${ }^{\circledR}$ wiesen nach 500 Sterilisationsdurchgängen bei vier von fünf Zangen eine Lötstellenveränderung auf $(p=0,068)$. Die untersuchten Zangen der Hersteller unterschieden sich somit nicht signifikant.

Der Lochfraß trat nur bei der Desinfektion mit Sekusept Extra $\mathrm{N}^{\circledR}$ auf (Abbildung 10). Die Zangen von ETM und HuFriedy ${ }^{\circledR}$ waren im Vergleich zu den Zangen von Aesculap ${ }^{\circledR}$ signifikant anfälliger für Lochfraß $(p=0,011)$. Eine Beschichtungsablösung trat nur bei den ETM-Zangen auf, da nur diese eine Chrombeschichtung haben (Abbildung 11). Dies trat sowohl bei Hitzesterilisation als auch bei der High-level-Desinfektion in gleichem Maße auf.

\section{Diskussion}

In der vorliegenden Studie wurden kieferorthopädische Zangen vor und nach Hitzesterilisation bzw. nach High-levelDesinfektion mit Sekusept Extra ${ }^{\circledR}$ im Ultraschallbad untersucht. Die Thermosterilisation wurde gewählt, da sie eine in der Praxis angewandte Methode ist [1, 3, 14]. Sekusept Extra $\mathrm{N}^{\circledR}$ wurde in dieser Studie verwendet, da es, obwohl es bis jetzt noch keine in der Praxis angewendete Methode ist, eine sehr schnelle Art der High-level-Desinfektion für die Zukunft darstellen könnte und die Effizienz dieses Mittels in einer Studie bereits nachgewiesen wurde [2]. Der Vorteil der Hitzesterilisation sowie der Kaltsterilisation mit Sekusept Extra $\mathrm{N}^{\circledR}$ ist die praxisorientierte Anwendung. Nach entsprechender Instruktion können diese Methodiken durch entsprechendes Personal (Dentalassistentin) durchgeführt werden. Ein weiterer Vorteil ergibt sich aus dem geringen Zeitaufwand beider Methoden. Dieser führt gleichzeitig zu Einsparungen von Kosten, da dadurch weniger Material angeschafft werden muss. Die Anschaffungs- und Materialkosten sind im Vergleich zu anderen Sterilisationsverfahren nicht sehr hoch.

Die Zangen wurden sowohl lichtmikroskopisch als auch rasterelektronenmikroskopisch auf Korrosionsschäden untersucht. Die Art der Korrosionsschäden wurde zusätzlich statistisch in einem Auswertungsbogen analysiert, wobei die Korrosionsarten davor sorgfältig ausgesucht wurden. Zur Auswahl dienten hauptsächlich verschiedene DIN-Normen [9]. Im Wesentlichen kann eine Oberflächenkorrosion von einem Lochfraß unterschieden werden. Diese beiden Korrosionsarten unterscheiden sich dabei qualitativ. Während die Oberflächenkorrosion nicht in die Tiefe der Legierung eindringt, kann der Lochfraß durch entsprechend tieferes Eindringen zu einem Stabilitätsverlust der Zange führen. Zudem begünstigt er die weitere Korrosion. Unsere Untersuchungen konnten aufzeigen, dass die Oberflächenkorrosion insbesondere bei der Hitzesterilisation auftritt. Ein Unterschied bei den einzelnen Zangentypen konnte nicht festgestellt werden. 
fore affect the stability of the pliers. It also encourages further corrosion. Our study also showed that surface corrosion was particularly associated with heat sterilization. No difference could be found between the different types of pliers. A thorough drying of the pliers prior to sterilization is thus recommended. Furthermore, the manufacturers' recommended care procedures should be adhered to following sterilization.

The qualitatively more destructive pitting was evident in this study following cold sterilization. The pliers from Aesculap ${ }^{\circledR}$ showed the fewest changes. Even after 500 sterilization cycles, no increase in pitting was seen. Their pliers can also be used with cold disinfection. This study showed that pitting is a kind of corrosion especially prevalent with cold sterilization using chemicals, and it occurred in Weingart pliers and distal-end cutters to the same degree. This can be explained by the similar alloys used in each type of pliers from the same manufacturer.

The electron microscope study was intended to supplement the EDX analysis, a more accurate method in ascertaining the change in iron oxide content [20]. However, it is not possible to guarantee that the same criteria are fulfilled for each site on the pliers. The most important factors to monitor, whether examining grindings or flat surfaces (e.g. wires or brackets), are that the distance from the location being measured be identical and the angle the same, otherwise there will doubtless be discrepancies. This is why our EDX analysis to determine alloy composition was made on grindings. The EDX analysis is a less complicated method than other methods reported in the literature (such as atom absorption spectrometry).

In order to include a method applicable in practice, light microscopy was chosen to identify corrosion damage. The advantages of light microscopy and EDX analysis are that they are fast, easy, and reliable methods. It should not be difficult for trained personnel (such as dental assistants) to obtain the results and print them out as a table including statistical analysis. The electron microscope's disadvantage is that, to obtain a good assessment, grindings must be taken, and this is more time-consuming.

\section{Conclusions}

The pliers from Hu-Friedy ${ }^{\circledR}$ are more prone to corrosion than the chrome-coated pliers from ETM. The chrome plating on the EMT pliers did not, however, provide really effective protection from corrosion, since the plating wears off after 200 cycles. The pliers from Aesculap ${ }^{\circledR}$ showed the least corrosion. This study showed that heat sterilization caused less corrosion than chemical sterilization. We are, however, certain that regular oiling of the pliers, particularly around the hinge joints, would improve the situation. The resistance to corrosion depends on the correct handling of the pliers by trained staff, as advised by the manufacturer. Correct handling is particularly important with re-
Ein sorgfältiges Trocknen der Zangen vor der Sterilisation ist daher zu empfehlen. Weiterhin sind entsprechende Pflegemaßnahmen der Hersteller nach Sterilisation einzuhalten.

Der qualitativ ungünstigere Lochfraß entstand in dieser Studie bei Anwendung der Kaltdesinfektion. Die Zangen des Herstellers Aesculap ${ }^{\circledR}$ zeigten hier die geringsten Veränderungen. Auch nach 500 Zyklen konnte keine weitere Zunahme von Lochfraß bei diesen Zangen festgestellt werden. Letztgenannte Zangen können damit auch für die High-levelDesinfektion mit Kaltdesinfektion genutzt werden. Diese Studie konnte zeigen, dass Lochfraß eine Korrosionsart ist, die besonders bei Desinfektions- und Sterilisationsverfahren mit Chemikalien auftritt. Er trat im gleichen Verhältnis bei Weingartzangen und Distalendcuttern auf. Dieser Befund lässt sich durch die gleichen Legierungen der Zangentypen je Hersteller erklären.

Bei der rasterelektronenmikroskopischen Untersuchung wurde absichtlich darauf verzichtet, die EDX-Analyse anzuwenden, obwohl sie eine sichere Methode ist, die Veränderung des Eisenoxidgehaltes zu bestimmen [20]. Bei Zangen ist es nicht möglich, an jeder Stelle die gleichen Voraussetzungen zu gewährleisten. Die wichtigsten Voraussetzungen sind der gleiche Abstand zum Messpunkt sowie der gleiche Winkel, welcher nur bei Schliffen oder geraden Flächen (z.B. bei Drähten oder Brackets) einstellbar ist. Dies hätte zu indiskutablen Abweichungen geführt. Deshalb wurde die EDX-Analyse, um die Legierungsbestandteile zu erhalten, an Schliffen angewendet. Im Vergleich zu anderen, in der Literatur beschriebenen Verfahren wie z.B. der Atomabsorptionsspektrometrie ist die EDX-Analyse jedoch eine leicht durchzuführende Methode.

Um eine Methodik zu nutzen, welche auch in der Praxis angewendet werden kann, wurden die kieferorthopädischen Zangen lichtmikroskopisch auf Korrosionsschäden untersucht. Die Vorteile sowohl der lichtmikroskopischen Untersuchung als auch der EDX-Analyse sind eine einfache, schnelle und sichere Durchführung. Die Auswertung mit anschlieBender statistischer Erhebung in der Auswertungstabelle sollte ohne Probleme von geschultem Personal (MTA, ZMA) durchgeführt werden können. Nachteile treten bei der rasterelektronenmikroskopischen Untersuchung insofern auf, als, um möglichst gute Voraussetzungen zu erreichen, Schliffe gemacht werden müssen, was einen erheblichen Zeitaufwand darstellt.

\section{Schlussfolgerungen}

Die Zangen von Hu-Friedy ${ }^{\circledR}$ sind im Vergleich zu den chrombeschichteten Zangen von ETM korrosionsanfälliger. Die Chrombeschichtung der ETM-Zangen stellte jedoch keinen wirksamen Schutz gegen Korrosion dar, da bereits nach 200 Zyklen Ablösungen der Schicht auftraten. Die Zangen der Firma Aesculap ${ }^{\circledR}$ wiesen die wenigsten Korrosionserscheinungen auf. Diese Studie zeigte, dass bei Hitzesterilisation die Materialschäden geringer sind als bei der Kaltdesin- 
spect to the mechanical disturbance of the passive layer that helps to minimize corrosion.

\section{Acknowledgement}

The authors would like to thank the manufacturers Aesculap ${ }^{\circledR}$, ETM, Hu-Friedy ${ }^{\circledR}$ and Pluradent for providing the materials for this study.

\section{References}

1. Angelini E. Influence of sterilization on the corrosion resistance of high-speed dental hand pieces. Quintessenc Int 1992;23:215-22.

2. Bader F. Viruzide, bakterizide und fungizide Effekte praxisnaher Desinfektionsmaßnahmen bei kieferorthopädischen Zangen. Ulm: Med Diss, 1997.

3. Bapna MS, Müller HJ. Corrosion of dental burs in sterilizing and disinfection solutions. J Prosthet Dent 1998;59:503-11.

4. Borchmann M. Schadensfälle an zahnärztlichen Instrumenten (I). Quintessenz 1990;41:1863-70.

5. Borchmann M. Schadensfälle an zahnärztlichen Instrumenten (II). Quintessenz 1990;41:2033-8.

6. Borneff J, Borneff M. Hygiene. Stuttgart - New York: Thieme, 1991:428-78.

7. Borneff M. Hygiene für Zahnmediziner. Stuttgart - New York: Thieme, 1994:35-93.

8. DIN 12880. Elektrische Laborgeräte; Wärmeschränke; Prüfung. Berlin - Köln: Beuth, 1975.

9. DIN 50900. Korrosion der Metalle. Berlin - Köln: Beuth, 1975.

10. Draeger J, Prüter J-W. Eignung verschiedener Verfahren zur Sterilisation von mikrochirurgischen Instrumenten. Klin Monatsbl Augenheilkd 1990;197:133-7.

11. Eleazer PD. Lack of corrosion of stainless steel instruments in vivo by Scanning Electron Microscope and microprobe analysis. J Endo 1991;17:346-50.

12. Henkel KgaA. Gutachtenmappe für Sekusept Extra N. Düsseldorf: Henkel Hygiene, 1992.

13. Hornbogen E, Strotzki B. Werkstoffmikroskopie. Berlin - Heidelberg - New York: Springer, 1993.

14. Jones ML. An initial assessment of the effect on orthodontic pliers of various sterilization/disinfection regimes. $\mathrm{Br} \mathrm{J}$ Orthod $1989 ; 16: 251-58$

15. Kratzenstein B, Weber H, Geis-Gerstorfer J, Koppenburg P. In-vivoKorrosionsuntersuchungen an kieferorthopädischen Apparaturen. Dtsch Zahnärztl Z 1985;40:1146-50.

16. Masunaga MI. Corrosion of instruments. J Clin Orthod 1987;21: 331-6. fektion. Wir sind uns jedoch sicher, dass die Korrosionsbeständigkeit der Zangen, besonders im Bereich der Zangengelenke, durch regelmäßiges Ölen verbessert werden kann. Die Korrosionsbeständigkeit kann zudem durch schonenden Umgang mit den Zangen, durch geschultes Personal, wie es auch von den Herstellern verlangt wird, verbessert werden. Der schonende Umgang ist besonders wichtig, da es ansonsten zu einer mechanischen Zerstörung der gebildeten Passivschicht kommt, was eine leichtere Korrosionsbildung zur Folge hat.

\section{Danksagung}

Die Autoren danken den Firmen Aesculap ${ }^{\circledR}$, ETM, Hu-Friedy ${ }^{\circledR}$ sowie Pluradent für die Bereitstellung des Untersuchungsmaterials.

17. Ohnsorge J, Holm R. Rasterelektronenmikroskopie. Stuttgart - New York: Thieme, 1978:98-123.

18. Thompson RPJ, Bogues WHJP. An investigation into methods used to clean and sterilize orthodontic instruments and bands. $\mathrm{Br} \mathrm{J}$ Orthod 1989;16:251-8.

19. Wendler-Kalsch E. Korrosion. 2.Korrosionsarten. Zentr Steril 1994;2:114-6.

20. Wichelhaus A, Culum T, Sander FG. Untersuchungen zur Oberflächenzusammensetzung kieferorthopädischer Legierungen unter besonderer Berücksichtigung des Nickelanteils. Inf Orthod Kieferorthop 1997; 29:51-69.

\section{Correspondence Address}

Prof. Dr. Andrea Wichelhaus

Department of Orthodontics and Paediatric Dentistry

Hebelstr. 3

4056 Basel

Switzerland

Phone (+41/61) 2672-641, Fax -657

e-mail: Andrea.Wichelhaus@unibas.ch 